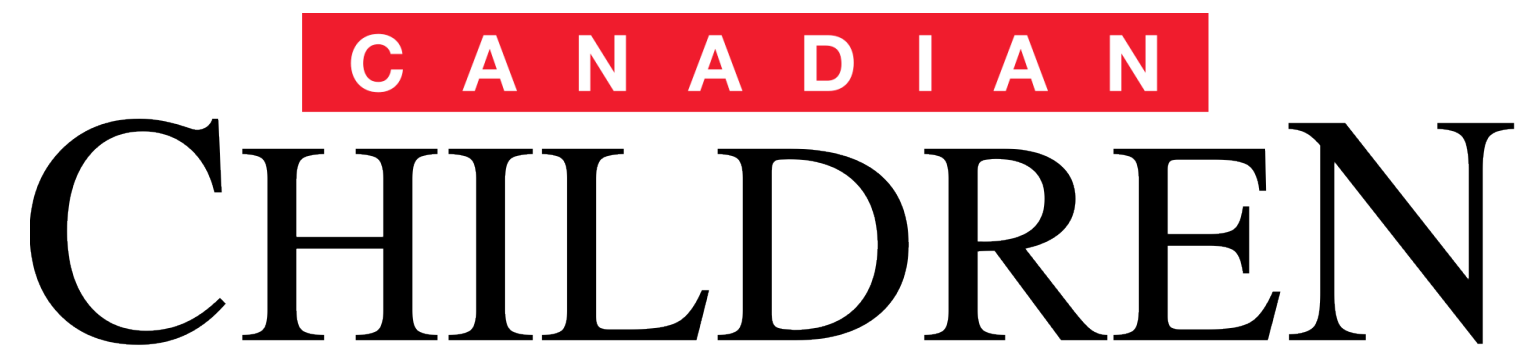

JOURNAL OF THE CANADIAN ASSOCIATION FOR YOUNG CHILDREN

Winter 2015/Hiver 2015

Vol. 40 No. 1

\title{
ECEs as Childcare Advocates: Examining the Scope of Childcare Advocacy Carried Out By ECEs from the Perspective of Childcare Movement Actors in Ontario and Manitoba
}

By Lyndsay Macdonald, Brooke Richardson, and Rachel Langford

C A N A D I A N

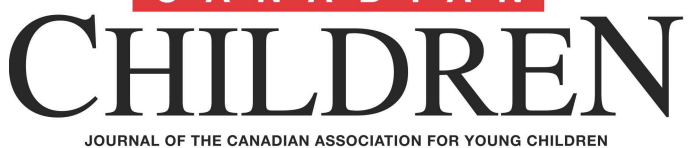

Winter 2015/Hiver 2015

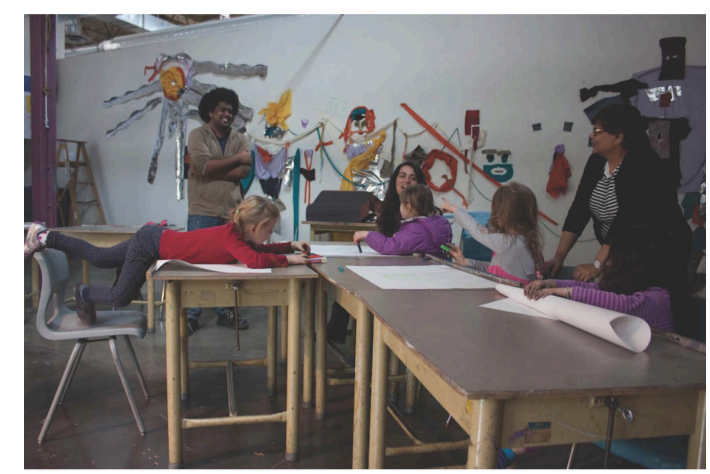

Editors:

Dr. Laurie Kocher, Douglas College, Coquitlam, British Columbia Dr. Veronica Pacini-Ketchabaw, University of Victoria, Victoria, British Columbia

Guest Editors, Special Issue: Professionalism in ECEC Dr. Rachel Langford, Dr. Jane Hewes, Sonya Hooper, and Monica Lysack

Publications Chairperson:

Dr. Iris Berger,

University of British Columbia,

Vancouver, British Columbia

Cover Photo:

Dr. Sylvia Kind

(c) 1996: The Canadian Association for Young Children ISSN: 0833-7519

Author Guidelines: visit www.cayc.ca

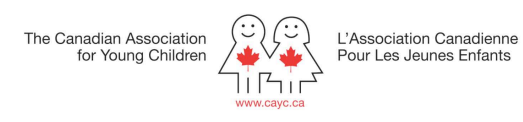

The Canadian Association
for Young Children

Published with support from the Social Sciences and Humanities Research Council of Canada

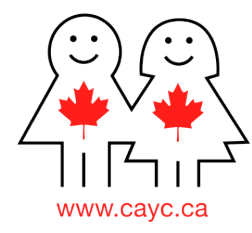




\title{
Canadian Children
}

\section{JOURNAL OF THE CANADIAN ASSOCIATION FOR YOUNG CHILDREN}

Volume 40 Number 12015 [page 100 to 110]

www.cayc.ca

\section{ECEs as Childcare Advocates: Examining the Scope of Childcare Advocacy Carried Out by ECEs from the Perspective of Childcare Movement Actors in Ontario and Manitoba}

\section{by Lyndsay Macdonald, Brooke Richardson, and Rachel Langford}

\begin{abstract}
Authors' Bios
Lyndsay Macdonald, MA, Early Childhood Studies, Ryerson University, is a research officer at the Childcare Resource and Research Unit and also works as the part-time coordinator for the Child Care Advocacy Association of Canada. Email: lmacdonald@childcarecanada.org

Brooke Richardson, MA, teaches part-time in the early childhood studies program at Ryerson University while completing her PhD in policy studies, also at Ryerson. Email: brichard@ryerson.ca

Rachel Langford, PhD, is the director of the School of Early Childhood Studies, Ryerson University. Email: rlangfor@ryerson.ca
\end{abstract}

\begin{abstract}
This paper examines the commonly held notion that early childhood educators (ECEs) "don't make good advocates." While most childcare advocates interviewed in this qualitative study disagreed with this blanket statement, informants had reservations about the scope of advocacy in which ECEs could and should engage. They made clear distinctions between "silent," "small a," and "big A"—or micro/meso/macro level—advocacy. Furthermore, informants from both Manitoba and Ontario appear to suggest that ECEs are best suited, able, and willing to carry out "small a" advocacy (though there was some variation in this finding by province). Guided by the political economy of care, this paper critically examines the etiology and sociopolitical consequences of advocacy carried out by ECEs primarily at the micro level. Insights into how ECEs may be able to expand the scope of advocacy beyond the micro level without compromising or undermining their professional identity are explored.
\end{abstract}


Comparisons of early childhood education and care (ECEC) policy and services have identified Canada as an international laggard (Organisation for Economic Cooperation and Development, 2006; UNICEF, 2008). In 2008, Canada met only one of ten benchmarks of comprehensive ECEC policy, ranking 25 out of 25 developed nations (UNICEF, 2008). Similarly, the Organisation for Economic Cooperation and Development (OECD, 2006) has described the Canadian ECEC sector as "in its initial stages" (p. 6). Today, in 2014, little progress has been made. Accessible, affordable, high-quality childcare services remain elusive for many Canadian children and parents. Similarly, early childhood educators (ECEs) remain grossly undervalued for their work, often earning minimum wage or slightly above (Flanagan, Beach, \& Varmuza, 2013). While there is overwhelming consensus that "the quality of early childhood education and care depends above all else on the ability of the caregiver to build relationships with children, and to help provide a secure, consistent, sensitive, stimulating, and rewarding environment" (UNICEF, 2008, p. 23), the supports necessary for ECEs to facilitate such an environment (i.e., adequate remuneration, good working conditions) are often absent. While the sector continues down a path of instability, there has been and continues to be a heightened focus on "professionalizing" ECEs. Adhering to a code of ethics, establishing minimal training requirements, and encouraging professional development of ECEs has been strongly encouraged and in some cases mandated. Unfortunately, the discussion rarely acknowledges the underlying problem: the funding to recruit and retain a better-educated and compensated workforce does not exist in the market-based system of childcare we currently have in Canada.

Historically, the Canadian childcare advocacy movement has been spearheaded and maintained by leaders in the women's movement, unions, and grassroots community organizations/coalitions (Friendly \& Prentice, 2009). However, a shifting political economy entrenched in neoliberal ideals is increasingly weakening the capacity of government and community organizations to effect progressive ECEC policy change in Canada. Government institutions such as the National Action Committee for the Status of Women have been shut down completely. The Child Care Advocacy Association of Canada, a key national childcare advocacy organization, is still operational but has been defunded and is fighting to survive. As a result, there has been an increasing reliance on unions, which are also struggling to do more with less, to sustain the struggling childcare movement. These shifts are indirectly necessitating the involvement of ECE professionals in the struggle for affordable, accessible, and highquality child care. The question becomes "Who will be the advocates for a comprehensive, affordable, accessible, publicly funded ECEC system where ECEs are adequately trained and remunerated?" Unfortunately, "advocate" and ECE "professional" are often viewed as contradictory, rather than complementary, roles. This paper examines whether ECEs can be advocates from the perspective of childcare movement actors in Manitoba and Ontario.

\section{Canadian Children}




\section{Feminist Political Economy of Care and the Social Reproduction Squeeze}

This study was rooted in a feminist political economy of care framework. This perspective highlights how the downloading of responsibility for social reproduction from the state to individuals has impacted women, particularly mothers and professionals in caregiving roles (Bezanson \& Luxton, 2006). Mothers continue to struggle to balance paid and unpaid work (Dobrowolsky, 2009), often facing pressures to make their family responsibilities invisible in the workplace (Arat-Koc, 2006). Approximately 3 out of 4 mothers of preschoolaged children are working (Vanier Institute of the Family, 2013), demonstrating a clear need for affordable, accessible, high-quality childcare spaces. In 2001, the OECD recommended that "early childhood services should be recognized, like compulsory schooling, as a public good and as an important part of the education process" (Organisation for Economic Cooperation and Development, 2001, p. 58).

Unfortunately, Canadian child care quality, accessibility, and affordability have devolved since that time, moving further into the private, market-based sphere. Funding to public and/or not-for-profit childcare operations has been cut significantly, allowing private, for-profit operators to step in and become a significant provider of much-needed childcare spaces (Lloyd \& Penn, 2012). Given that the primary goal of for-profit childcare operators is to make a profit and that existing not-for-profit childcare centres are operating on shoestring budgets, ECE professionals suffer the consequences in terms of inadequate wages and working conditions. Some have suggested that ECEs are subsidizing child care in Canada through their near poverty-level wages (Child Care Human Resources Sector Council, 2009).

Finally, the downloading of social reproduction from the state to individuals has contributed to the struggling state of the Canadian childcare movement. The founders of childcare advocacy in Canada are slowly retiring from the movement while a younger generation of women, overburdened with their paid and unpaid responsibilities, struggles to help keep the movement alive. These shifts in the feminist political economy have meant that mothers, early childhood educators, and women more generally are left vulnerable to a state that significantly undervalues care work in both paid and unpaid settings. Child care remains a private responsibility provided either by parents (usually mothers) or a commodity to be purchased through the market.

\section{What Do We Mean By "Professionalism" and "Advocacy"?}

Most definitions of professionalism in the ECE field highlight the possession and application of technical and theoretical knowledge (e.g., Chandler, 2012). Not surprisingly, many concrete steps have been taken in Canada to professionalize ECEs and the child care sector: increased training requirements; a regulatory body protecting the ECE title for those with a predetermined level of training (in Ontario); mandated professional development; the development of a code of ethics; and the introduction of curriculum frameworks. In contrast, Moriarty (2000) has argued for a more inclusive definition of ECE professionalism that 
includes engagement in public debates and policy discussions. Such public policy engagement would typically be considered an advocacy activity rather than a professional activity in that one enters public policy discussions from a particular perspective with a particular interest which she or he is attempting to further. Such action departs from the technical acquisition and application of knowledge. Instead it involves embracing one's own experiences, opinions, and values - the very antithesis of what is often considered objective and professional. Academics confirm that ECEs do not typically engage in advocacy as such, either for their profession or for an adequate childcare system (Moss, 2006; Moyles, 2001; Woodrow \& Busch, 2008). This paper examines and questions the often contradictory images of a professional and an advocate.

\section{Methodology}

This study used secondary interview data from an ongoing three-year Social Sciences and Humanities Research Council (SSHRC) funded study that is examining the effects of ECE workforce sector professionalization on the Canadian childcare movement. For this project, interview data from 14 childcare movement actors, seven in Ontario and seven in Manitoba, were analyzed. Informants were associated with one of four organizations: the Ontario Coalition for Better Child Care (OCBCC), the Association of Early Childhood Educators of Ontario (AECEO), the Child Care Coalition of Manitoba (CCCM), or the Manitoba Child Care Association (MCCA).

\section{Findings}

All of the informants from Manitoba and Ontario, with the exception of one, expressed the opinion that ECEs could be advocates. However, the conceptualizations of advocacy varied in scope. Three overlapping and interacting levels of advocacy became apparent: micro ("silent"), meso ("small a") and macro ("big A"). Micro-level advocacy is defined as simply conducting oneself as a professional (e.g., following a code of ethics, engaging in best practices). Some informants considered such behaviour as advocacy in its own right. Mesolevel advocacy includes advocating at the program level (e.g., securing services for a child with special needs, fundraising, assisting a family to obtain a subsidy). Finally, macro-level advocacy includes challenging the larger sociopolitical order and is consistent with Moriarty's (2000) argument that ECEs should be engaged in public discussions about ECEC policy. 
Table 1. Three levels of advocacy.

\begin{tabular}{|c|c|c|}
\hline Scope & Description & Example/Quote \\
\hline $\begin{array}{l}\text { Micro } \\
\text { ("silent") }\end{array}$ & $\begin{array}{l}\text { Conducting oneself ethically and professior } \\
\text { in one's day-to-day work (e.g., establishing } \\
\text { positive and collaborative relationships wit } \\
\text { colleagues, children, and families) }\end{array}$ & $\begin{array}{l}\text { "If you're working in an ethical mann } \\
\text { you are promoting quality in every } \\
\text { decision that you make then you are } \\
\text { advocating for quality and to me they } \\
\text { one in the same." }\end{array}$ \\
\hline $\begin{array}{l}\text { Meso } \\
\text { ("small a") }\end{array}$ & $\begin{array}{l}\text { Actively speaking up for children and famil } \\
\text { at the centre level (e.g., helping families } \\
\text { navigate the subsidy system, securing } \\
\text { additional services, fundraising for the } \\
\text { centre/program) }\end{array}$ & $\begin{array}{l}\text { "I would say, am I working within a c } \\
\text { of ethics? Values? Do I advocate on b } \\
\text { of the families and children that I wo } \\
\text { with?" }\end{array}$ \\
\hline $\begin{array}{l}\text { Macro } \\
\text { ("big A") }\end{array}$ & $\begin{array}{l}\text { Actively seeking out opportunities to challe } \\
\text { the prevailing social-political order that } \\
\text { negates the value of ECEs and early childho } \\
\text { education (e.g., participating in / organizin } \\
\text { rallies, writing to politicians) }\end{array}$ & $\begin{array}{l}\text { "Some of our long-time AECEO memb } \\
\text {... they would say, 'absolutely, I can } \\
\text { advocate,' you know, they're the ones } \\
\text { who on their own will write letters to } \\
\text { their politicians and so on." }\end{array}$ \\
\hline
\end{tabular}

Micro-level ("silent") advocacy

"Being professional," "acting like a professional," and "professionalism" were frequently included as characteristics of advocacy. An informant from Manitoba suggested:

If you're working in an ethical manner you are promoting quality in every decision that you make then you are advocating for quality and to me they're one in the same.

When discussing professionalism and advocacy, an informant from Ontario said:

You start thinking very small, you start thinking what you can do with the families in your program and the children in your program and how you can deliver the best program for them.

Another informant from Manitoba reiterated the idea that behaving like a professional in one's day-to-day work could be considered advocacy:

Sometimes you can be a silent advocate in your work and it can be just as effective as somebody screaming from the rooftops, so it depends on the scenario.

So, while all but one informant agreed that professionals could be advocates, advocacy was often limited to a silent form in which behaving professionally was considered advocacy. 
Meso-level ("small a") advocacy

The majority of informants identified meso-level advocacy as a common practice. "Small a" advocacy was conceptualized as advocating on behalf of the families and children in a childcare environment. A veteran ECE and staff member of Manitoba's professional childcare association included advocacy at the program level as a component of one's professional role:

What do I believe professionalism means? I would say, am I working within a code of ethics? Values? Do I advocate on behalf of the families and children that I work with? Am I committed to life-long learning and realizing that this is a career and not just a jumping point to work somewhere else?

Another informant from Manitoba included sharing experiences as an ECE within their immediate community as advocacy:

I try to tell [ECEs], just tell your story, and that is advocating.

Overall, most informants discussed advocacy on the meso level as a suitable and typical form of advocacy for ECEs. A number of informants offered explanations as to why micro- and meso-level advocacy are preferred. The sentiment that ECEs hesitate to engage in macro-level advocacy because they are "overworked," "tired," or don't perceive themselves as "worthy" emerged. An informant from Ontario noted that ECE advocacy rarely reaches the macro level because ECEs are putting their energies into stabilizing their immediate work environment:

We've got centres that are just trying to keep their doors open ... so here in Ottawa everybody started putting their heads down just figuring out how they are going to keep their doors open.

It also became evident that informants felt ECEs were ill equipped to advocate publicly or speak on bigger-picture issues:

We've seen good uptake if you give someone a sign and say come to this rally and hold up your sign, they can do that. If you say to them meet with your MLA, well that just becomes too much for people and that goes back to a lack of knowledge and a lack of confidence.

Finally, another informant suggested that a lack of leadership in the field was a reason that advocacy fails to move beyond micro and meso levels:

I see that we've had a real issue in cultivating leaders ... we are such a giving and caring sector, why don't we do that for each other? We're so focused on families and children, which is like - of course I believe in that and I idolize it, but why not ourselves? 
Macro-level ("big A") advocacy

Informants from Ontario were generally more optimistic than informants from Manitoba about ECEs' ability to engage in "big A" advocacy. An informant from Ontario linked ECEs' ability to engage in macro-level advocacy to their involvement with the professional childcare association:

In some of our meetings that we've done around the province I find that, increasingly, ECEs who are more part of the AECEO are also coming to our meetings and showing that they understand that it has to be a big picture approach, it has to be about a strong, funded, stable system.

Another informant from Ontario provided an optimistic perspective about the future of ECE professionals as childcare advocates:

There is a renaissance to be seen, we will have ECE professionals publicly advocating.... With ECEs on the ground, they see the impact of social programs or lack thereof or cutbacks or what have you. So they, in fact, can speak with on-the-ground experience of what the needs are.

From this informant's perspective, ECEs can be involved in all levels of advocacy. Two informants from the AECEO similarly identified their own members as likely advocates for larger system issues:

I think [ECE professionals] make good advocates, but I think it's difficult, you know, if you were to go out there and you were to interview some of our long-time AECEO members who have always considered themselves professionals ... they would say, 'absolutely I can advocate, 'you know, they're the ones who on their own will write letters to their politicians and so on.

I want to see a viral campaign that just focuses on ECEs.... There's 40,000 registered ECEs in Ontario. Everyone knows an ECE and they know the commitment and they know what they do. I think that we need the best advocates to be the broader society and the ECE professionals themselves.

Among all of the informants, only one stated that ECE professionals did not make good advocates specifically because of what this informant described as ECEs' personal and professional characteristics:

I don't think childcare people make good advocates because they're too nice, and you know, our people are first of all caregivers and it's a challenge to get people to tell their stories publicly.... Our people are fixers, they're quite used to fixing all of their

\section{Canadian Children}


own problems as fast as they can.... To get them to speak up on an issue is very difficult and they're very shy about it.

\section{Discussion}

So can ECEs be advocates? Informants (who are not practicing ECEs) overwhelmingly agreed that ECEs have the potential to be strong advocates. On further analysis, however, it became evident that the scope of advocacy referred to was usually limited to micro and meso levels. Current engagement of ECEs in "big A" advocacy challenging the prevailing notion that child care is a private responsibility rather than a public good appeared to be lacking. While a handful of informants were hopeful that ECEs could become more engaged in "big A" activities in the future, micro- and meso-level advocacy appeared to be more commonly perceived as realistic across interviews.

As mentioned above, it is important to recognize that the identified levels of advocacy are not mutually exclusive categories. One who is able to maintain a professional practice is more likely to be knowledgeable about the various services and systems available to the children and families with whom they work. As a result of these meso-level advocacy experiences, professionals are likely better prepared to mobilize themselves and their peers to make clearly articulated demands of government representatives. At the same time, it is entirely possible and plausible that some "big A" advocates focus their energy mainly on the larger system issues rather than specifically advocating for individual children or families in their program or centre. These categories are simply helpful to better understand the past, current, and future scope of ECE-led advocacy efforts by those who have been and/or continue to be engaged in the childcare advocacy movement.

It is also important to note the limitations of the "silent" advocacy category itself. Some may argue that being silent and advocating are mutually exclusive activities. That informants considered maintaining a professional practice as advocacy at all was one of our most interesting and surprising findings. We in no way mean to obfuscate the importance of professional practice by using the term silent advocacy. However, the data necessitated broadening the conceptualization of advocacy to include this silent category.

A feminist political economy perspective suggests that to meaningfully address women's equity, care work must be reframed as a public good. However, the current social reproduction squeeze has meant that mothers and women more generally are struggling to keep child care in the public eye and on the political agenda. This study has revealed that ECEs are not currently taking on macro-level childcare advocacy - even though their personal and professional well-being is often at stake. While academics agree that ECEs must be encouraged to challenge "conceptions of marketization within the early years" (Moriarty, 2000, p. 240) and the "privatization and domestication of care" (Taggart, 2011, p. 86), the reality is that ECEs have not yet been able to consistently engage in the political issues that underlie their undervalued role within society. 
Several reasons why ECEs primarily engage in micro- and meso- rather than macrolevel advocacy emerged through this analysis: (1) a lack of understanding or knowledge about larger system and policy issues; (2) a lack of confidence on the part of ECEs; (3) a lack of time to devote to the broader advocacy movement; and (4) instability of the field, including the immediate work environment. In regard to the first point, ECE training programs rarely include ECE policy courses that provide preservice ECEs with the necessary tools to critically question the system in which they work. There has been a focus in many training programs on professionalism, but, like advocacy, this concept is limited. Professionalism is too often conceptualized as applying technical knowledge rather than developing the professional autonomy to critically reflect on and discuss the larger political issues around the childcare system (Urban, 2010).

Practical barriers also appeared to prevent ECEs from engaging in "big A" advocacy. Simply put, the day-to-day work of an ECE is hectic. Daily tasks include not only the direct care and education of young children, but programming, budgeting, communicating with parents, collaborating with a board of directors/owner, and more. All this leaves little time for ECEs to critically reflect and engage in dialogue with their peers. If ECEs were presented with flexible opportunities to meet and discuss their work in relation to the broader sector, it might facilitate unity within this ever-fragmented sector. As Moyles (2001) points out, "working in partnership with researchers, early years practitioners have shown themselves able to engage in high level, critical reflection on their own practices, to link associated theory and to challenge political prescription" (p. 90). In essence, ECE professionalism has the potential to shift from the application of prescribed skills in the classroom to the critical and active participation of ECEs in the broader sector.

Fortunately, a handful of informants felt optimistic about ECEs' interest, ability, and willingness to engage in "big A" advocacy efforts. According to one informant, the "best advocates are ECE professionals themselves." However, the responsibility of advocacy cannot be yet one more task added to the underresourced ECE's "to do" list. ECEs must be systematically supported emotionally, financially, and intellectually to overcome these barriers identified by informants. Support from childcare centre directors, ECE faculty, childcare groups, researchers, unions, and other ECEC-related organizations is necessary for ECEs to be comfortable, confident, and able to engage in "big A" advocacy. In addition to providing support, the movement itself must provide the necessary space for ECEs to engage in larger advocacy efforts. Unfortunately, ECEs may never be involved in the childcare advocacy movement if its leaders and champions do not see a place for them. As it stands, ECEs can be seen as an untapped resource for childcare advocacy mobilization efforts - a resource desperately needed to keep progressive childcare policy discussion — and action — alive. 


\section{References}

Arat-Koc, S. (2006). Whose social reproduction? Transnational motherhood and challenges to feminist political economy. In K. Bezanson \& M. Luxton (Eds.), Social reproduction: Feminist political economy challenges neo-liberalism (pp. 75-92). Montreal, QC: McGill-Queen's University Press.

Bezanson, K., \& Luxton, M. (Eds.). (2006). Social reproduction: Feminist political economy challenges neo-liberalism. Montreal, QC: McGill-Queen's University Press.

Chandler, K. (2012). Administering for quality: Leading Canadian early childhood programs $\left(4^{\text {th }}\right.$ ed). Don Mills, ON: Pearson Education Canada.

Child Care Human Resources Sector Council. (2009). Portrait of Canada's early childhood education and care workforce. Ottawa, ON: Author.

Dobrowolsky, A. (2009). Women and public policy in Canada: Neo-liberalism and after? Don Mills, ON: Oxford University Press.

Flanagan, K., Beach, J., \& Varmuza, P. (2013). You bet we still care: A survey of centre-based early childhood education and care in Canada. Highlights report. Ottawa, ON: Child Care Human Resources Sector Council.

Friendly, M., \& Prentice, S. (2009). About Canada: Child care. Halifax, NS: Fernwood.

Lloyd, E., \& Penn, H. (2012). Childcare markets: Can they deliver an equitable service? Bristol, UK: Policy Press.

Moriarty, V. (2000). Early years educators in Finland and England: Issues of professionality. International Journal of Early Years Education, 8(3), 235-241.

Moss, P. (2006). Structures, understandings, and discourses: Possibilities for re-envisioning the early childhood worker. Contemporary Issues in Early Childhood Education Research Journal, 15(1), 5-20.

Moyles, J. (2001). Passion, paradox, and professionalism in early years education. Early Years, 21(2), 81-95.

Organisation for Economic Co-operation and Development. (2001). Starting Strong: Early childhood education and care. Directorate for Education. Paris, France: Author.

Organisation for Economic Co-operation and Development. (2006). Starting Strong II: Early childhood education and care. Directorate for Education. Paris, France: Author.

Taggart, G. (2011). Don't we care?: The ethics and emotional labour of early years professionalism. Early Years, 31(1), 85-95. 
UNICEF. (2008). The child care transition: A league table of early childhood education and care in economically advanced countries. Report Card 8. Florence, Italy: UNICEF Innocenti Research Centre.

Urban, M. (2010). Dealing with uncertainty: Challenges and possibilities for the early childhood profession. In C. Dalli \& M. Urban (Eds.), Professionalism in early childhood education and care: International perspectives (pp. 4-22). Oxon, UK: Routledge.

Vanier Institute of the Family. (2013). Mothers in Canada: By the numbers. Retrieved from: http://www.vanierinstitute.ca/include/get.php?nodeid=3702

Woodrow, C., \& Busch, G. (2008). Repositioning early childhood leadership as action and activism. European Early Childhood Education Research Journal, 16(1), 83-93. 


\section{In this issue:}

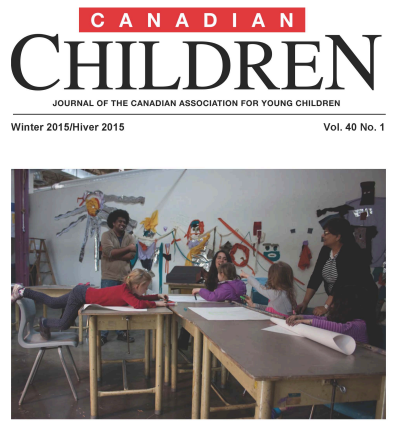

From the Editors' Desk Special Issue: Professionalism in ECEC Guest Editors: Dr. Rachel Langford, Dr. Jane Hewes, Sonya Hooper, and Monica Lysack

Beyond Professionalism: Interrogating the Idea and the Ideals by Randa Khattar and Karyn Callaghan

Negotiating Status: The Impact of Union Contracts on the Professional Role of RECEs in Ontario's Full-Day Kindergarten Program by Romona Gananatham

The Glass Ceiling Effect: Mediating Influences on Early Years Educators' Sense of Professionalism by Stefanie Tukonic and Debra Harwood

Enhancing Professionalism and Quality Through Director Training and Collegial Mentoring by Glory Ressler, Gillian Doherty, Tammy McCormick Ferguson, and Jonathan Lomotey

Authoring Professional Identities: Immigrant and Refugee Women's Experiences in an Early Childhood Teacher Education Program by Christine Massing

ECEs as Childcare Advocates: Examining the Scope of Childcare Advocacy Carried out by ECEs from the Perspective of Childcare Movement Actors in Ontario and Manitoba by Lyndsay Macdonald, Brooke Richardson, and Rachel Langford

From Child-Minders to Professionals: Insights From an Action Research Project on Prince Edward Island by Anna Baldacchino, Ray Doiron, Martha Gabriel, Alaina Roach O'Keefe, and Jessica McKenna

Pedagogical Narrations and Leadership in Early Childhood Education as Thinking in Moments of Not Knowing by Iris Berger

Find other articles from this issue at www.cayc.ca 